\title{
Effects of Health Information and Generic Advertising on U.S. Meat Demand
}

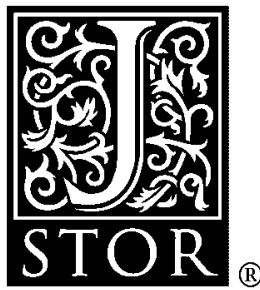

\author{
Henry W. Kinnucan; Hui Xiao; Chung-Jen Hsia; John D. Jackson \\ American Journal of Agricultural Economics, Vol. 79, No. 1. (Feb., 1997), pp. 13-23.
}

Stable URL:

http://links.jstor.org/sici?sici=0002-9092\%28199702\%2979\%3A1\%3C13\%3AEOHIAG\%3E2.0.CO\%3B2-S

American Journal of Agricultural Economics is currently published by American Agricultural Economics Association.

Your use of the JSTOR archive indicates your acceptance of JSTOR's Terms and Conditions of Use, available at

http://www.jstor.org/about/terms.html. JSTOR's Terms and Conditions of Use provides, in part, that unless you have obtained prior permission, you may not download an entire issue of a journal or multiple copies of articles, and you may use content in the JSTOR archive only for your personal, non-commercial use.

Please contact the publisher regarding any further use of this work. Publisher contact information may be obtained at http://www.jstor.org/journals/aaea.html.

Each copy of any part of a JSTOR transmission must contain the same copyright notice that appears on the screen or printed page of such transmission.

The JSTOR Archive is a trusted digital repository providing for long-term preservation and access to leading academic journals and scholarly literature from around the world. The Archive is supported by libraries, scholarly societies, publishers, and foundations. It is an initiative of JSTOR, a not-for-profit organization with a mission to help the scholarly community take advantage of advances in technology. For more information regarding JSTOR, please contact support@jstor.org. 


\title{
Effects of Health Information and Generic Advertising on U.S. Meat Demand
}

\author{
Henry W. Kinnucan, Hui Xiao, Chung-Jen Hsia, and John D. Jackson
}

\begin{abstract}
The dominant pattern in U.S. meat consumption over the past two decades has been a steady increase in per capita poultry consumption, largely at the expense of beef consumption. Our findings suggest that the major factor governing this pattern is structural change. Specifically, health information or trend was found to be significant in each of the four equations estimated in the Rotterdam system. Moreover, the health-information elasticities in general are larger in absolute value than price elasticities, which suggests that small percentage changes in health information have larger impacts on meat consumption than equivalently small percentage changes in relative prices. The estimated effects of generic advertising, in contrast, were found to be modest and fragile.
\end{abstract}

Key words: generic advertising, health information, meat demand, structural change.

This study focuses on whether generic advertising and health information have detectable effects on U.S. meat demand. This question is of interest because previous studies suggest that generic advertising and health information, when examined in isolation, do indeed influence meat consumption patterns (Ward and Lambert, Capps and Schmitz, McGuirk et al.). However, no study to our knowledge has examined the combined effects of advertising and health information on U.S. meat consumption. The side-by-side comparison of responses to generic advertising and health information permits testing of attribution and related theories (Mizerski), which have an important bearing on the optimal allocation of resources to promotion, research, and other market-devel-

Henry W. Kinnucan and Hui Xiao are professor and graduate-research assistant, respectively, Department of Agricultural Economics and Rural Sociology, Auburn University; Chung-Jen Hsia is an economist with the Council of Agriculture, Taiwan; and John D. Jackson is a professor in the Economics Department, Auburn University.

The paper benefitted from seminar participants' comments at Texas A\&M and Cornell University. Wen Chern and Dong-Kyoon Kim of Ohio State University graciously shared data to update the cholesterol information index. Appreciation is expressed to Rob Martin, Walt Prevatt, and two anonymous reviewers for their helpful comments. Funds supporting this research were provided in part by a grant from the National Institute for Commodity Promotion Research and Evaluation. Responsibility for final content, however, rests with the authors. Scientific Journal Paper No. 1955142 of the Alabama Agricultural Experiment Station. opment activities (Chang and Kinnucan).

As a by-product of our analysis, we examine the robustness of the estimated parameters to sample updating. Interest in the robustness issue stems in part from a growing concern about whether empirical results are cumulative in the sense that replication with new or updated data would confirm previous findings (Robinson and Colyer). Tomek argues that replication, i.e., estimating the same model with new or updated data, is essential for sound policy, learning, and research innovation. Moreover, the role of taste change in explaining trends in U.S. meat demand has proved controversial. Some studies confirm the hypothesîs of structural change (e.g., Sakong and Hayes), while others disconfirm or question it (e.g., Eales and Unnevehr). The conflicting findings argue for increased attention to robustness when reporting empirical findings.

The chief aim of this research is to determine the effects of health information and generic advertising on meat consumption patterns in the United States. A secondary objective is to determine the validity of Theil's theory that advertising responses are proportional to price responses. We begin by discussing the model, data, and estimation procedures. The empirical results to establish robustness and test hypotheses are then presented. The paper concludes with a summary of the major findings. 


\section{Model}

The Rotterdam model was selected because it is consistent with demand theory (Barten 1964, Theil 1965); it is as flexible as any other local approximating form (Mountain); it lends itself to advertising applications (e.g., Brown and Lee 1993, Duffy 1987); and it is more consistent with U.S. meat demand behavior than its major rival, the (linear approximate) Almost Ideal Demand System (Alston and Chalfant).

Several approaches can be used to augment the Rotterdam specification to include advertising or health information effects. The most common approach, suggested by Theil (1980), is to view advertising as a "taste shifter" that affects marginal utility. In this formulation, advertising enters the model as a price deflator (e.g., Duffy 1987, p. 1053). An alternative approach, advocated by Stigler and Becker, is to view advertising (or other information sources) as an input in the household production function. In this formulation, advertising enters the (derived) demand function for market goods as a separate shift variable along with prices and income (e.g., Verma).

Because the household-production approach embeds the Theil approach as a special case (Brown and Lee 1992), following Capps and Schmitz and Piggot and Griffith we specify advertising and health information as separate shift variables in the absolute-price version of the Rotterdam model. ${ }^{1}$ The system consists of demand equations for beef, pork, poultry (chicken and turkey) and fish. Thus, weak separability of the meat group is treated as a maintained hypothesis and total meat expenditure is used in place of income in the model.

The data time interval has been shown to be important in modeling advertising effects. For example, Duffy (1990) found that a Rotterdam model estimated with annual data had significant advertising effects, while the same model estimated with quarterly data had insignificant advertising effects. Clarke's analysis suggests that annual data in general produce upward biased estimates of advertising responses. For products with short purchase cycles (e.g., food items), Clarke recommends the use of quarterly or, preferably, monthly data.

Because monthly data were unavailable, the model is specified in quarterly form. A one-period distributed lag in advertising and health information is specified. This implies a total re-

\footnotetext{
${ }^{1}$ For a clear discussion of the distinction between the absoluteand relative-price versions of the Rotterdam model in an advertising context, see Selvanathan.
}

sponse interval of six months: three months in the initial quarter and three months in the carryover period. The six-month response interval is consistent with Clarke's finding that most studies of frequently purchased, low-cost, mature products indicate an advertising carryover period of three to nine months. It is also consistent with Ward and Lambert's study of beef advertising, which "...consistently pointed to the inclusion of only [one lagged term]" (p. 459) in their quarterly model. Brester and Schroeder (p. 978) state "...[the] effects of advertising on quarterly consumption of meats dissipate rapidly." ${ }^{2}$ The symmetrical treatment of advertising and health information with respect to lag structure is consistent with Chang and Kinnucan's approach to the problem. The basic specification is as follows:

$$
\begin{array}{r}
w_{i} d \ln q_{i}=a_{i}+b_{i} d \ln Q+\sum_{j}^{4} c_{i j} d \ln p_{j} \\
+\sum_{k}^{3} d_{i k} d \ln A_{k}+\sum_{k}^{3} e_{i k} d \ln A_{k-1} \\
+f_{i} d \ln Z+g_{i} d \ln Z_{-1}+\sum_{m}^{3} h_{i m} D_{m}+v_{i}
\end{array}
$$

where $i$ indexes the equation $(i=1,2,3,4$ for beef, pork, fish, and poultry, respectively) and $d \ln Q=\Sigma_{i} w_{i} d \ln q_{i}$ is the Divisia volume index, which can be interpreted as a third-order approximation to real expenditure on the meat group (Goldberger, p. 95).

In this model, $w_{i}$ corresponds to the expenditure share of meat item $i$ in time period $t, q_{i}$ denotes per capita consumption of meat item $i$ in time period $t, p_{j}$ is the nominal price of meat item $j$ in time period $t, A_{k}$ is the real per capita generic advertising expenditure on meat item $k$ in period $t, Z$ is a health information index, and $v_{t}$ is a random error term. ${ }^{3}$ Because the model is

\footnotetext{
${ }^{2}$ The one-period lag is also supported by statistical tests. In particular, likelihood-ratio tests for lag lengths of $-2,-3$, and -4 (based on 1976-93 data) produced chi-square values of 3.48 , -0.14 , and 5.05 ; the corresponding critical values at the $5 \%$ level are $21.03,36.42$, and 50.71 . Thus, the hypothesis that meat advertising effects dissipate rapidly (within one calendar quarter following the original expenditure) is supported by these data.

${ }^{3} \mathrm{~A}$ reviewer suggested that some advertising might be a response to health information, in which case $A$ and $Z$ are related and the error term in equation (1) may not be random. To test this, we performed Granger causality tests, which indeed failed to reject the null hypothesis that the two series are unrelated. Specifically, based on four-period lag structures, health information was found to Granger-cause beef and pork (but not fish) advertising. Based on these findings, we estimated the model using 3SLS with lagged values of advertising and health information serving as instruments for contemporaneous advertising. The results, however, were unencouraging: standard errors throughout the system were inflated and estimated advertising effects had counterintuitive signs in some cases. Thus, it appears that the bias/precision tradeoff favors ignoring the causality findings.
} 
based on quarterly data, three binary variables $D_{m}$ are specified to account for seasonal shifts in meat demands. An intercept is included in equation (1) to test whether trend-related changes in demographics or meat composition affect meat demand. ${ }^{4}$

An implicit assumption underlying equation (1) is that brand advertising has no effect on aggregate demand. Thus, poultry advertising, which is strictly brand based, is excluded from the model. A justification for this assumption is that brand advertising, by definition, is directed at shifting the market shares of individual firms and not necessarily at enlarging the size of the total market. The chief aim of generic advertising, by contrast, is market expansion. ${ }^{5}$

Symmetry and homogeneity are tested in equation (1) by imposing, respectively, the restrictions $c_{i j}=c_{j i}$ for all $i$ and $j$ and $\Sigma_{j} c_{i j}=0$ for all $i$. Advertising coefficients must sum to zero, i.e., $\Sigma_{k} d_{i k}=0$ and $\Sigma_{k} e_{i k}=0$ for all $i$, to satisfy the advertising homogeneity condition (Selvanathan, p. 219). ${ }^{6}$

Theil's (1980) theory that advertising affects the marginal utility of the advertised good but leaves the marginal utility of other goods unchanged implies that the advertising coefficients in equation (1) are proportional to the negative of the price coefficients (e.g., see Duffy 1987, p. 1053). However, to satisfy demand theory, the price coefficients in equation (1) must be symmetric. Thus, Theil's proportionality hypothesis, when combined with the price-symmetry hypothesis, is tantamount to assuming that advertising coefficients are sym-

\footnotetext{
${ }^{4}$ We thank Sheila Corrington of the National Livestock and Meat Board for bringing to our attention the potential importance of compositional changes. For example, the portion of young chicken slaughter going into further processed products between 1976 and 1987 (the latest available figure) increased from $7.1 \%$ to 22.4\% (Perez, Weimar, and Cromer, tables 86 and 87). Assuming compositional changes occurred gradually over the sample period, the Rotterdam model's intercept, which is interpreted as a trend variable, will reflect the compositional change.

${ }^{5}$ Although it would have been preferable to test the hypothesis that brand advertising has no effect on the aggregate demand, data limitations prevented this. In particular, the published data source (Leading National Advertisers) is too aggregated to permit accurate identification of brand expenditures by meat category. For example, while it is clear that expenditures listed under the Beef Industry Council is for beef advertising, it is less clear that expenditures listed under Swift, Oscar Mayer, Tyson, or Hormel is for beef, pork, poultry, or some combination thereof. To the extent that brand advertising does indeed affect aggregate demand, the estimated (direct) effects for generic advertising will be biased upward, assuming brand and generic advertising are related.

${ }^{6}$ As pointed out by a reviewer, the homogeneity condition need not hold if one or more commodities in the system is not advertised. This is particularly true for the equation(s) pertaining to zero advertising (e.g., poultry in our system). For these equations, the advertising elasticities, which are strictly cross-elasticities, may well sum to less than zero. Advertising homogeneity, therefore, is not imposed in the final estimation.
}

metric. ${ }^{7}$ Advertising symmetry, therefore, is tested by forming the following hypothesis:

$$
\begin{aligned}
& \mathrm{H}_{\mathrm{N}}: d_{i k}+e_{i k}=d_{k i}+e_{k i} \\
& \mathrm{H}_{\mathrm{A}}: \mathrm{H}_{\mathrm{N}} \text { not true }
\end{aligned}
$$

for all $i$ and $k$ with nonzero advertising. Hypothesis (2) represents a test of linear restrictions; hence, it can be tested using the Wald criterion (Greene 1993, pp. 187-89).

Engel aggregation requires that $\Sigma_{i} b_{i}=1$. Based on the proposition that an advertising-induced increase in the demand for one commodity must be offset by a decrease in the demand for at least one other commodity if the budget constraint is to be satisfied, Basmann (p. 53) developed an adding-up restriction for advertising responses, namely

$$
\sum_{i} w_{i} E_{i k}^{A}=0
$$

for all $k .^{8}$ In terms of equation (1), the Basmann aggregation condition implies that $\Sigma_{i} d_{i k}=0$ for the contemporaneous advertising responses, and $\Sigma_{i} e_{i k}=0$ for the lagged responses. From Basmann's analysis, it follows directly that the coefficients of $Z$ and $Z_{-1}$ must also sum to zero across equations, i.e., $\Sigma_{i} f_{i}=0$ and $\Sigma_{i} g_{i}=0$.

In estimation, one equation is dropped from the system to avoid singularity in the variance/ covariance matrix (Barten 1969). Because the adding-up conditions are used to obtain coefficients for the deleted equation, adding up is treated as a maintained hypothesis in the Rotterdam model. In addition, the differentials in equation (1) are approximated by first differences; thus, the intercepts must sum to zero, i.e., $\Sigma_{i} a_{i}=0$. Likewise, the seasonality coefficients must sum to zero, i.e., $\Sigma_{i} h_{i m}=0$ for all $m$. Further, the price coefficients across equations must sum to zero, i.e., $\Sigma_{i} b_{i j}=0$. Finally, the coefficients are regarded as fixed constants even though they embed budget shares, which generally change over time. Although these empirical details compromise the generality of the Rotterdam specification, the model is still regarded as a flexible approximation to an unknown demand system (Barnett, Mountain).

\footnotetext{
7 Selvanathan's analysis (p. 218) identifies a weaker form of symmetry, namely $d_{i k} \leq d_{k i}$ and $e_{i k} \leq e_{k i}$. The difference arises from a less restrictive assumption (than Theil's) about how advertising affects marginal utilities.

${ }^{8}$ Note that the Basmann aggregation condition does not imply that advertising is a zero-sum game; the appropriate test for the latter hypothesis is $\Sigma_{i} E_{i k}{ }^{A}=0$ for all $k$, i.e., the unweighted sum of the ownand cross-elasticities is zero for each advertised commodity.
} 
Elasticities are calculated using the following expressions:

$$
\begin{array}{ll}
\text { (expenditure elasticities) } & E_{i}^{Y}=b_{i} / w_{i} \\
\text { (Hicksian price elasticities) } & E_{i j}^{*}=c_{i j} / w_{i} \\
\text { (advertising elasticities) } & E_{i k}^{A}=\left(d_{i k}+e_{i k}\right) / w_{i} \\
\text { (health info. elasticities) } & E_{i}^{H}=\left(f_{i}+g_{i}\right) / w_{i}
\end{array}
$$

Expenditure elasticities are expected to be positive, own-price elasticities negative, and generally the Hicksian cross-price elasticities are expected to be positive, since meat products are generally considered to be normal goods and to substitute for each other. The own-advertising elasticities should be positive and the cross-advertising elasticities negative. The health information elasticities are expected to be positive for poultry and fish and negative for beef and pork because red meat consumption is implicated in heart disease and health authorities encourage the consumption of fish and poultry as a healthy alternative.

\section{Data and Estimation Procedure}

Data for the period 1976 through 1993 are used to estimate the model. However, two sample periods are chosen to test the robustness of estimated coefficients to sample updating. The data set established by Hsia covers 1976.I to 1991.III and serves as the basis for our baseline estimates. The updated sample adds nine observations to Hsia's original data set. ${ }^{9}$

Price and quantity data for beef, pork, and poultry were obtained from Putman and Allhouse and USDA's Livestock and Poultry Situation and Outlook Report. Price data for fish were obtained by dividing per capita expenditure data from a 1982-84 USDA survey by per capita fish consumption to get a base price. This base price was then multiplied by the quarterly CPI for fish to get a time series. Fish consumption data through 1991.III were obtained following the procedure outlined in Schmitz and Capps (p. 10); regression analysis was used to update the fish consumption data series through 1993.IV. (The actual data, along

\footnotetext{
9 The sample covers a period of substantial changes in the level of red meat and fish advertising. For example, expenditures on beef advertising in 1986, the year immediately preceding implementation of federal legislation authorizing the nationwide check-off program, was \$3.6 million; in 1987 expenditures jumped to $\$ 23.2$ million. No attempt was made in this study to determine whether the large increase in expenditures affected response coefficients.
}

with a more detailed description of the foregoing procedures, are contained in a data appendix available upon request from the authors.)

The advertising data were obtained from quarterly issues of $A D \$$ Summary published by the Leading National Advertisers, Inc. The beef, pork, and fish advertising data are those reported by LNA for the Beef Industry Council, the National Pork Producers Council, and the National Fish and Seafood Council, respectively. To accommodate the logarithmic specification of the Rotterdam model, the problem of zero advertising expenditures in some periods was addressed by adding a small positive number $(0.0001)$ to each observation (zero and positive values alike) after deflation by population and the CPI. The price deflater (CPI) is the general index for all items compiled by Bureau of Labor Statistics. The advertising data were placed on a per capita basis to be consistent with previous studies (e.g., Thompson and Eiler), although experimentation indicated that results are not sensitive to deflation.

A health information index was constructed using Brown and Schrader's cholesterol information index as basic data, updated through 1993.IV. Brown and Schrader developed two data series, one that indicated the cumulative sum of articles appearing in medical journals that support the link between blood serum cholesterol and heart disease ("negative information"), and another that indicated the cumulative number of articles that attacked or questioned the link ("positive information"). Following Chang and Kinnucan, we combined the two basic data series into a single index using the formula

$$
Z_{t}=\omega_{t} N E G_{t}
$$

where $Z_{t}$ is the "net-publicity" about the link between cholesterol and heart disease. In equation (4), $N E G_{t}$ is Brown and Schrader's "negative information" index, and $\omega_{t}$ is a weighting factor that indicates the relative proportion of all articles in period $t$ that are negative, i.e., $\omega_{t}$ $=N E G_{t} /\left(N E G_{t}+P O S_{t}\right)$ where $P O S_{t}$ is the cumulative total of "positive" articles. ${ }^{10}$

The model was estimated using seemingly

\footnotetext{
${ }^{10}$ A reviewer suggested that perhaps the negative and positive information might have different effects and therefore should be kept separate. Brown and Schrader (p. 549 and fn. 3), however, also combined the two series, arguing that positive and negative information had equal but opposite effects and, in any case, the positive information series was statistically insignificant. Moreover, the positive information (articles attacking the links) was small compared to the negative information: by 1987 , articles supporting the links outnumbered articles attacking the links by a factor of 23 (Brown and Schrader, p. 550).
} 
unrelated regressions (SUR) to accommodate the imposition of parametric restrictions. The SUR procedure was selected because the Hausman test failed to detect a correlation between the price and expenditure terms and the error term in equation (1) in either the original or the updated sample (table 1). ${ }^{11}$ This suggests that for these data, prices and expenditures can be treated as exogenous for estimation purposes. $^{12}$

The adding-up constraint implies that only three equations in the system are independent. The usual procedure, followed in this study, is to drop one equation, estimate the remaining system, and to calculate the parameters from the omitted equation using the classical restrictions. The SUR procedure using maximum likelihood estimation for constrained systems produces estimates that are invariant to the deleted equation (Greene 1992, pp. 390-92). To facilitate tests of the advertising restrictions, we deleted the poultry equation. However, to assure robustness of parameter estimates to the deleted equation, and to obtain estimates of the standard errors of the "deleted" equation, we estimated the model twice: once with the poultry equation deleted, and again with the fish equation deleted.

Theoretical restrictions were successively imposed and tested using the Wald criterion. Based on these tests, an appropriately restricted model was used to test for advertising and health information effects and to estimate elasticities. All tests, unless indicated otherwise, use a significance level of $5 \%$. Elasticities are evaluated at sample mean budget shares.

\footnotetext{
1" The Hausman tests were conducted using the method described by Greene $(1993$, p. 287) as explained in table 1 (note a). The instrumental variables are the same as used by Eales and Unnevehr. Specifically, to capture supply-side influences we used an energy price index, corn price, ninety day treasury bill yields, meat packing plant wage rates, and fat removed from 100 pound pork carcasses. These variables, plus population and real per capita consumer income (as general demand-shifters), were added to the current and lagged values of the predetermined variables in equation (1) to form the instrument set. The instruments, along with data sources, are in an appendix available upon request from the authors.

${ }_{12}$ Technically, price exogeneity implies that (short-run) supply schedules for meat are horizontal. Horizontal supply at the farm level is implausible because of biological lags in the production of live animals and import controls. At retail, however, horizontal supply is perhaps less objectionable given excess capacity in meat processing, cold storage holdings, and the ability of retailers to import boxed beef and other processed meat items. Bronsard and Salvas-Bronsard's work suggests that price endogeneity is unimportant in demand system estimation when the commodities in question constitute a small portion of the consumer budget. (The meat group's budget share since 1985 is less than 3\%, USDA, p. 5 table 2.) McGuirk et al. (p. 17) and Brester and Schroeder (p. 973, note 7) failed to detect simultaneity in their annual and quarterly models, respectively, of U.S. meat demand.
}

Table 1. Hausman Tests for Price and Expenditure Exogeneity in U.S. Meat Demand, Original (1975.II - 1991.III) and Updated (1975.II -1993.IV) Samples

\begin{tabular}{lccl}
\hline Sample & Computed $\chi^{2}$ & Critical $\chi^{2}$ & Test Result \\
\hline Original & $11.64,7.48^{\mathrm{a}}$ & $25.00^{\mathrm{b}}$ & Fail to Reject \\
Updated & $9.73,12.90^{\mathrm{a}}$ & $25.00^{\mathrm{b}}$ & Fail to Reject \\
\hline
\end{tabular}

a Technically, the Hausman test requires that the covariance matrices of the SUR and 3SLS estimators be adjusted by the same estimated mean square error (Greene 1993, p. 287). For single-equation procedures, this adjustment amounts simply to multiplying one of the covariance matrices by a scalar equal to the ratio of the two estimated mean squared errors. For systems' estimators, the adjustment is not so straightforward. We mimic the single-equation procedure by multiplying each of the $17 \times 17$ ownequation covariance matrices obtained by the efficient (SUR) estimator by the appropriate ratio of mean squared errors and recomputing the test statistic for the system. The second number represents the chi-square value when this adjustment procedure is performed; the first number represents the chi-square value based on the unadjusted covariance matrices.

b Five percent level of significance. The degree of freedom is 15 , since five explanatory variables (meat expenditure and four price terms) are assumed to be endogenous in each of the three estimated equations, and the tests are performed without imposing the classical restrictions.

\section{Results}

Preliminary tests based on the Durbin-Watson statistic showed no evidence of serial correlation in the unrestricted equations. Wald tests for various combinations of the theoretical restrictions indicate that, regardless of sample period or combination of restrictions, all restrictions are compatible with the data (table 2). Of particular note is the compatibility of the advertising restrictions with the data, as these restrictions to our knowledge have not been tested before in the literature. Theil's hypothesis that advertising elasticities are proportional to price elasticities is consistent with these data.

Regression results for the model with price homogeneity and price and advertising symmetry imposed for the two sample periods are reported in tables 3 and 4 . (Although compatible with the data, advertising homogeneity is not imposed owing to the problems with interpreting this condition when the system contains unadvertised goods; see footnote 6 .) The relatively high $R^{2}$ 's, which range from 0.80 for beef and fish to 0.92 for pork, coupled with a preponderance of significant coefficients, suggest the restricted model provides a good fit to the data. The results overall suggest that meat demands are subject to seasonal variation and trend effects. Estimated price effects and expenditure effects in general are consistent with 
Table 2. Wald Tests of Theoretical Restrictions

\begin{tabular}{|c|c|c|c|c|c|}
\hline \multirow[b]{2}{*}{ Restriction } & \multicolumn{2}{|c|}{ Computed $\chi^{2}$} & \multirow{2}{*}{$\begin{array}{c}\text { Critical } \chi^{2} \\
5 \% \text { level of } \\
\text { Significance }\end{array}$} & \multicolumn{2}{|c|}{ Test Result } \\
\hline & $\begin{array}{l}\text { Original } \\
\text { Sample }\end{array}$ & $\begin{array}{l}\text { Updated } \\
\text { Sample }\end{array}$ & & $\begin{array}{l}\text { Original } \\
\text { Sample }\end{array}$ & $\begin{array}{l}\text { Updated } \\
\text { Sample }\end{array}$ \\
\hline PH, PS & 4.85 & 9.02 & 12.59 & Fail to Reject & Fail to Reject \\
\hline PH, PS, AH & 10.38 & 14.44 & 16.92 & Fail to Reject & Fail to Reject \\
\hline PH, PS, AS & 7.18 & 11.77 & 16.92 & Fail to Reject & Fail to Reject \\
\hline $\mathrm{PH}, \mathrm{PS}, \mathrm{AH}, \mathrm{AS}$ & 10.69 & 15.64 & 21.03 & Fail to Reject & Fail to Reject \\
\hline
\end{tabular}

Note: $\mathrm{PH}=$ price homogeneity, $\mathrm{PS}=$ price symmetry, $\mathrm{AH}=$ advertising homogeneity, and AS = advertising symmetry.

Table 3. SUR Estimates of the Rotterdam Model with Homogeneity, Symmetry, and Advertising Symmetry Restrictions Imposed, Original Sample

\begin{tabular}{|c|c|c|c|c|}
\hline \multirow{2}{*}{$\begin{array}{l}\text { Independent } \\
\text { Variables }\end{array}$} & \multicolumn{4}{|c|}{ Dependent Variables } \\
\hline & $Q B E E F$ & $Q P O R K$ & QPOULT & $Q F I S H$ \\
\hline$P B E E F$ & $\begin{array}{l}-0.21883 \\
(-5.385)\end{array}$ & & & \\
\hline PPORK & $\begin{array}{l}0.15023 \\
(7.502)\end{array}$ & $\begin{array}{l}-0.16027 \\
(-9.272)\end{array}$ & & \\
\hline PPOULT & $\begin{array}{l}0.05145 \\
(3.688)\end{array}$ & $\begin{array}{l}-0.01573 \\
(-1.811)\end{array}$ & $\begin{array}{l}-0.02607 \\
(-2.539)\end{array}$ & \\
\hline PFISH & $\begin{array}{l}0.01714 \\
(0.521)\end{array}$ & $\begin{array}{l}0.02576 \\
(1.403)\end{array}$ & $\begin{array}{l}-0.00965 \\
(-0.804)\end{array}$ & $\begin{array}{l}-0.03326 \\
(-0.902)\end{array}$ \\
\hline EXPENDITURE & $\begin{array}{l}0.51763 \\
(8.449)\end{array}$ & $\begin{array}{l}0.24739 \\
(6.139)\end{array}$ & $\begin{array}{l}0.00765 \\
(0.339)\end{array}$ & $\begin{array}{c}0.22733 \\
(3.532)\end{array}$ \\
\hline $\mathrm{CHO}_{\mathrm{t}}$ & $\begin{array}{l}-0.29505 \\
(-1.883)\end{array}$ & $\begin{array}{l}0.10510 \\
(1.017)\end{array}$ & $\begin{array}{l}0.17139 \\
(3.018)\end{array}$ & $\begin{array}{l}0.01856 \\
(0.144)\end{array}$ \\
\hline$C H O_{t-1}$ & $\begin{array}{l}-0.05744 \\
(-0.366)\end{array}$ & $\begin{array}{l}-0.15319 \\
(-1.478)\end{array}$ & $\begin{array}{l}0.08460 \\
(1.464)\end{array}$ & $\begin{array}{l}0.12603 \\
(0.771)\end{array}$ \\
\hline$B F A D_{t}$ & $\begin{array}{l}-0.00077 \\
(-1.191)\end{array}$ & $\begin{array}{l}0.00042 \\
(1.133)\end{array}$ & $\begin{array}{l}-0.00045 \\
(-1.193)\end{array}$ & $\begin{array}{l}0.00079 \\
(1.389)\end{array}$ \\
\hline$B F A D_{t-1}$ & $\begin{array}{c}0.00135 \\
(1.974)\end{array}$ & $\begin{array}{l}-0.00038 \\
(-0.934)\end{array}$ & $\begin{array}{l}-0.00068 \\
(-1.821)\end{array}$ & $\begin{array}{l}-0.00030 \\
(-0.503)\end{array}$ \\
\hline$P K A D_{t}$ & $\begin{array}{l}-0.00021 \\
(-0.938)\end{array}$ & $\begin{array}{l}-0.00003 \\
(-0.166)\end{array}$ & $\begin{array}{l}0.00003 \\
(0.268)\end{array}$ & $\begin{array}{l}0.00022 \\
(1.161)\end{array}$ \\
\hline$P K A D_{t-1}$ & $\begin{array}{l}0.00026 \\
(1.141)\end{array}$ & $\begin{array}{l}0.00003 \\
(0.182)\end{array}$ & $\begin{array}{l}-0.00011 \\
(-1.106)\end{array}$ & $\begin{array}{l}-0.00018 \\
(-0.949)\end{array}$ \\
\hline$F S A D_{t}$ & $\begin{array}{l}0.00022 \\
(0.917)\end{array}$ & $\begin{array}{l}-0.00006 \\
(-0.415)\end{array}$ & $\begin{array}{l}0.00008 \\
(0.879)\end{array}$ & $\begin{array}{l}-0.00023 \\
(-0.927)\end{array}$ \\
\hline$F S A D_{t-1}$ & $\begin{array}{l}0.00028 \\
(1.175)\end{array}$ & $\begin{array}{l}0.00001 \\
(0.656)\end{array}$ & $\begin{array}{l}-0.00015 \\
(-1.725)\end{array}$ & $\begin{array}{l}-0.00022 \\
(-0.886)\end{array}$ \\
\hline$D 1$ & $\begin{array}{c}0.03230 \\
(7.917)\end{array}$ & $\begin{array}{c}-0.03490 \\
(-12.816)\end{array}$ & $\begin{array}{c}-0.03367 \\
(-21.489)\end{array}$ & $\begin{array}{l}0.03626 \\
(8.377)\end{array}$ \\
\hline$D 2$ & $\begin{array}{l}0.00919 \\
(2.280)\end{array}$ & $\begin{array}{l}-0.04026 \\
(-15.327)\end{array}$ & $\begin{array}{l}-0.00237 \\
(-1.620)\end{array}$ & $\begin{array}{l}0.03344 \\
(8.009)\end{array}$ \\
\hline D3 & $\begin{array}{l}0.00247 \\
(0.603)\end{array}$ & $\begin{array}{c}-0.02898 \\
(-10.344)\end{array}$ & $\begin{array}{l}-0.00540 \\
(-3.522)\end{array}$ & $\begin{array}{c}0.03191 \\
(7.499)\end{array}$ \\
\hline INTERCEPT & $\begin{array}{l}-0.00557 \\
(-1.157)\end{array}$ & $\begin{array}{l}0.02673 \\
(8.376)\end{array}$ & $\begin{array}{c}0.00639 \\
(3.608)\end{array}$ & $\begin{array}{l}-0.02755 \\
(-5.503)\end{array}$ \\
\hline $\mathrm{R}^{2}$ & 0.8281 & 0.9185 & & 0.8008 \\
\hline D-W Stat ${ }^{a}$ & 2.9524 & 2.3338 & & 2.9136 \\
\hline
\end{tabular}

Note: Numbers in parenthesis are the $t$-values for the parameter estimates.

a Durbin-Watson $d$ Statistic: $n=61, k^{\prime}=16, a=0.01, d_{L}=0.857, d_{U}=2.120$, the Zone of indecision is $1.88-3.143$. 
Table 4. SUR Estimates of the Rotterdam Model with Homogeneity, Symmetry, and Advertising Symmetry Restrictions Imposed, Updated Sample

\begin{tabular}{|c|c|c|c|c|}
\hline \multirow{2}{*}{$\begin{array}{l}\text { Independent } \\
\text { Variables }\end{array}$} & \multicolumn{4}{|c|}{ Dependent Variables } \\
\hline & $Q B E E F$ & $Q P O R K$ & QPOULT & $Q F I S H$ \\
\hline$P B E E F$ & $\begin{array}{l}-0.22547 \\
(-5.478)\end{array}$ & & & \\
\hline PPORK & $\begin{array}{c}0.13933 \\
(6.741)\end{array}$ & $\begin{array}{l}-0.16918 \\
(-9.260)\end{array}$ & & \\
\hline PPOULT & $\begin{array}{l}0.04881 \\
(3.822)\end{array}$ & $\begin{array}{l}-0.01626 \\
(-1.971)\end{array}$ & $\begin{array}{l}-0.02519 \\
(-2.623)\end{array}$ & \\
\hline PFISH & $\begin{array}{l}0.03734 \\
(1.094)\end{array}$ & $\begin{array}{l}0.04611 \\
(2.336)\end{array}$ & $\begin{array}{l}-0.00736 \\
(-0.680)\end{array}$ & $\begin{array}{l}-0.07608 \\
(-1.951)\end{array}$ \\
\hline EXPENDITURE & $\begin{array}{c}0.36643 \\
(7.636)\end{array}$ & $\begin{array}{c}0.18189 \\
(5.578)\end{array}$ & $\begin{array}{l}0.00822 \\
(0.538)\end{array}$ & $\begin{array}{c}0.44346 \\
(8.426)\end{array}$ \\
\hline $\mathrm{CHO}_{\mathrm{t}}$ & $\begin{array}{l}-0.43020 \\
(-2.681)\end{array}$ & $\begin{array}{l}-0.00275 \\
(-0.025)\end{array}$ & $\begin{array}{l}0.16589 \\
(3.235)\end{array}$ & $\begin{array}{l}0.26707 \\
(1.518)\end{array}$ \\
\hline $\mathrm{CHO}_{t-1}$ & $\begin{array}{c}0.13402 \\
(0.840)\end{array}$ & $\begin{array}{l}-0.05483 \\
(-0.507)\end{array}$ & $\begin{array}{l}0.08091 \\
(1.549)\end{array}$ & $\begin{array}{l}-0.16010 \\
(-0.927)\end{array}$ \\
\hline$B F A D_{t}$ & $\begin{array}{l}-0.00013 \\
(-0.395)\end{array}$ & $\begin{array}{l}-0.00032 \\
(-1.543)\end{array}$ & $\begin{array}{l}-0.00017 \\
(-1.517)\end{array}$ & $\begin{array}{c}0.00062 \\
(1.929)\end{array}$ \\
\hline $\begin{array}{c}B F A D_{t-1} \\
\cdot\end{array}$ & $\begin{array}{l}-0.000003 \\
(-0.010)\end{array}$ & $\begin{array}{l}0.00046 \\
(2.084)\end{array}$ & $\begin{array}{l}-0.00011 \\
(-0.925)\end{array}$ & $\begin{array}{l}-0.00035 \\
(-1.026)\end{array}$ \\
\hline$P K A D_{t}$ & $\begin{array}{l}-0.00020 \\
(-1.002)\end{array}$ & $\begin{array}{l}-0.00003 \\
(-0.211)\end{array}$ & $\begin{array}{c}0.00001 \\
(0.099)\end{array}$ & $\begin{array}{l}0.00022 \\
(1.102)\end{array}$ \\
\hline$P K A D_{t-1}$ & $\begin{array}{l}0.00033 \\
(1.653)\end{array}$ & $\begin{array}{l}0.00005 \\
(0.286)\end{array}$ & $\begin{array}{l}-0.00013 \\
(-1.381)\end{array}$ & $\begin{array}{l}-0.00025 \\
(-1.226)\end{array}$ \\
\hline$F S A D_{t}$ & $\begin{array}{l}0.00001 \\
(0.040)\end{array}$ & $\begin{array}{l}-0.00019 \\
(-1.189)\end{array}$ & $\begin{array}{l}0.00010 \\
(1.312)\end{array}$ & $\begin{array}{c}0.00007 \\
(0.273)\end{array}$ \\
\hline$F S A D_{t-1}$ & $\begin{array}{l}0.00026 \\
(1.153)\end{array}$ & $\begin{array}{c}0.00015 \\
(0.984)\end{array}$ & $\begin{array}{l}-0.00011 \\
(-1.426)\end{array}$ & $\begin{array}{l}-0.00030 \\
(-1.154)\end{array}$ \\
\hline$D 1$ & $\begin{array}{c}0.02599 \\
(7.130)\end{array}$ & $\begin{array}{c}-0.03687 \\
(-14.693)\end{array}$ & $\begin{array}{c}-0.03387 \\
(-27.922)\end{array}$ & $\begin{array}{c}0.04475 \\
(11.103)\end{array}$ \\
\hline$D 2$ & $\begin{array}{c}0.01679 \\
(4.392)\end{array}$ & $\begin{array}{c}-0.03673 \\
(-14.122)\end{array}$ & $\begin{array}{l}-0.00317 \\
(-2.561)\end{array}$ & $\begin{array}{c}0.02311 \\
(5.567)\end{array}$ \\
\hline D3 & $\begin{array}{l}0.00934 \\
(2.304)\end{array}$ & $\begin{array}{l}-0.02539 \\
(-8.901)\end{array}$ & $\begin{array}{l}-0.00589 \\
(-4.354)\end{array}$ & $\begin{array}{l}0.02194 \\
(5.027)\end{array}$ \\
\hline INTERCEPT & $\begin{array}{l}-0.00831 \\
(-1.630)\end{array}$ & $\begin{array}{l}0.02538 \\
(7.272)\end{array}$ & $\begin{array}{c}0.00679 \\
(4.095)\end{array}$ & $\begin{array}{l}-0.02385 \\
(-4.305)\end{array}$ \\
\hline $\mathbf{R}^{2}$ & 0.7960 & 0.8943 & & 0.8317 \\
\hline D-W Stata & 2.9772 & 2.4307 & & 2.9915 \\
\hline
\end{tabular}

Note: Numbers in parenthesis are the $t$-values for the parameter estimates.

'Durbin-Watson $d$ Statistic: $n=70, k^{\prime}=16, a=0.01, d_{L}=0.974, d_{U}=2.038$, the Zone of indecision is $1.962-3.026$.

a priori expectations. However, sufficient differences exist in the original and updated estimates to suggest that inferences are sensitive to sample updating, especially with respect to estimated advertising effects.

\section{Price Effects}

The major difference in the estimated price effects between the original and updated samples pertains to fish. In the original sample, none of the price effects pertaining to fish, including own-price, is significant. In the updated sample, the own-price effect for fish is significant and the cross-price effect of fish price with respect to pork consumption is significant and positive, indicating that fish is a net substitute for pork. The compensated own-price elasticities for the updated sample for beef, pork, poultry, and fish are $-0.444,-0.688,-0.158$, and -0.888 (table 5). These compare favorably with Capps and Schmitz's (p. 30) corresponding estimates of $-0.357,-0.451,-0.216$, and -0.273 based on 1966-88 annual data. The larger price elasticities for red meat products in the more 
recent period may reflect enhanced competition in the meat group due to the growth of aquacultural industries (e.g., catfish, crawfish, striped bass, and salmon). Alternatively, the earlier estimates may be biased as a result of the omission of trend or advertising effects.

\section{Expenditure Effects}

Estimated expenditure effects are consistent in the two samples. That is, total meat expenditure is a significant determinant of the demand for beef, pork, and fish, but not for poultry. Identical results were obtained by Capps and Schmitz (p. 29). Elasticity estimates, however, differ importantly between the samples, with the estimates for beef and pork decreasing and the estimate for fish increasing. (In fact, fish's expenditure elasticity in the updated sample is almost twice as large as the estimate for the original sample.) The updated-sample expenditure elasticities estimates are $0.721,0.739,0.051$ (insignificant), and 5.173 for beef, pork, poultry and fish (table 5). Capps and Schmitz' corresponding estimates are $0.900,1.889,0.227$ (insignificant), and 0.609 .

\section{Health Information Effects}

Estimated health-information effects are robust across the samples. Poultry appears to have benefited from the dissemination of cholesterol-related health information largely at the expense of beef. Pork and fish appear to have been unaffected by health information, although the significant intercept terms in the pork and fish equations suggest that other sources of structural change may be at work. Capps and Schmitz, by comparison, found that poultry gained from increases in health information at the expense of pork. The contemporaneous effects of health information in general are larger than the lagged effects. This, coupled with the insignificance of many of the lagged terms, suggests relatively rapid decay in health information effects.

That health concerns may play an important role in explaining meat consumption patterns is suggested by the magnitude of the estimated health information elasticities of 1.54 for poultry and -0.583 for beef (table 6 , updated sample). Given the relatively large increases in the health information index over the sample period, these elasticities hint at the potential importance of health information in explaining increases in poultry consumption and declines in beef consumption over time.

\section{Advertising Effects}

The robustness issue is most pronounced in the estimation of advertising effects. For example, using a $t$-ratio of 1.65 to indicate significancethe cut-off for a two-tail test at the $10 \%$ levelonly three out of a possible 24 estimated coefficients are significant in each sample. Moreover, the three significant coefficients obtained from the two sample periods are not the same. In the original sample, beef advertising (lagged one period) has a positive effect on beef demand and a negative effect on poultry demand. In the updated sample, beef advertising has a positive effect on pork and fish demand, but no effect on beef or poultry demand. By comparison, Brester and Schroeder (p. 977) find that generic advertising of beef and pork has a negative effect on poultry consumption, but no effect on the demand for beef or pork (fish is not ịncluded in their system).

The fragility of advertising parameters may be due to advertising's minor role in meat consumption behavior. For example, generic advertising intensities for meat items (advertising expenditure divided by industry revenue) are minuscule and advertising elasticities tend to be small compared to price and expenditure elasticities (compare tables 5 and 6). It may be asking too much of our econometric models to estimate reliably the effects of a variable whose effects are modest in any case. ${ }^{13}$

A second reason why estimated advertising parameters may be fragile relates to advertising measurement. As noted by Telser (p. 476), demand depends not so much on advertising outlays as on the number of messages consumers actually receive. The number (and quality) of messages that consumers actually receive is influenced inter alia by advertising copy, target audience, and media mix. The impact of these strategic decisions on message quantity (or quality) is not well reflected in a simple dollar measure of media exposure.

A related problem is that the tracking data reported by LNA may understate actual expenditures or misrepresent turning points (Kinnucan and Belleza). Thus, even if advertising expenditures measure the conceptually correct variable,

\footnotetext{
${ }^{13}$ This conjecture is confirmed by a log-likelihood ratio tests, which suggests that deleting the advertising variables in toto from the model does not result in a significant reduction in explanatory power.
} 
Table 5. Estimated Hicksian Price and Expenditure Elasticities for U.S. Meats, Rotterdam Model, Original and Updated Samples

\begin{tabular}{lcccc}
\hline & \multicolumn{4}{c}{ Quantity of } \\
\cline { 2 - 5 } With Respect to: & Beef & Pork & Poultry & Fish \\
\hline Beef Price & $-0.423^{*}$ & $0.610^{*}$ & $0.334^{*}$ & 0.210 \\
& $\left(-0.444^{*}\right)^{\mathrm{a}}$ & $\left(0.566^{*}\right)$ & $\left(0.305^{*}\right)$ & $(0.436)$ \\
Pork Price & $0.290^{*}$ & $-0.651^{*}$ & -0.102 & 0.315 \\
& $\left(0.274^{*}\right)$ & $\left(-0.688^{*}\right)$ & $\left(-0.102^{*}\right)$ & $\left(0.538^{*}\right)$ \\
Poultry Price & $0.099^{*}$ & -0.064 & $-0.169^{*}$ & -0.118 \\
& $\left(0.096^{*}\right)$ & $\left(-0.066^{*}\right)$ & $\left(-0.158^{*}\right)$ & $(-0.086)$ \\
Fish Price & 0.033 & 0.105 & -0.063 & -0.407 \\
& $(0.073)$ & $\left(0.187^{*}\right)$ & $(-0.046)$ & $\left(-0.888^{*}\right)$ \\
Meat Expenditure & $0.999^{*}$ & $1.005^{*}$ & 0.050 & $2.779^{*}$ \\
& $\left(0.721^{*}\right)$ & $\left(0.739^{*}\right)$ & $(0.051)$ & $\left(5.173^{*}\right)$ \\
\hline
\end{tabular}

Note: An asterisk indicates the coefficient is significant at the $5 \%$ level or lower.

a Number in parentheses is updated sample estimate.

Table 6. Estimated Health Information and Generic Advertising Elasticities for U.S. Meats, Rotterdam Model, Original and Updated Samples

\begin{tabular}{lcccc}
\hline & \multicolumn{4}{c}{ Quantity of: } \\
\cline { 2 - 5 } With Respect to: & Beef & Pork & Poultry & Fish \\
\hline Health Info & $-0.681^{*}$ & -0.195 & $1.659^{*}$ & 1.768 \\
& $\left(-0.583^{*}\right)^{\mathrm{a}}$ & $(-0.234)$ & $\left(1.543^{*}\right)$ & $(1.248)$ \\
Beef Adv & 0.00113 & 0.00019 & $-0.00732^{*}$ & 0.00608 \\
& $(-0.00026)$ & $(0.00056)$ & $(-0.00174)$ & $(0.00316)$ \\
Pork Adv & 0.00009 & 0.00001 & -0.00055 & 0.00043 \\
& $(0.00027)$ & $(0.00006)$ & $(-0.00074)$ & $(-0.00039)$ \\
Fish Adv & 0.00096 & 0.00014 & -0.00049 & -0.00559 \\
& $(0.00053)$ & $(-0.00014)$ & $(-0.00005)$ & $(-0.00266)$ \\
\hline
\end{tabular}

Note: An asterisk indicates the long-run coefficient (current plus lagged value) is (jointly) significant at the $10 \%$ level or lower.

" Number in parentheses is updated sample estimate. Elasticities are long run, i.e., they represent contemporaneous and lagged effects.

estimated advertising effects may be biased toward zero because of measurement error. However, downward biases caused by measurement error may be offset by upward biases associated with the omission of brand advertising in our models. Measurement and specification errors, to the extent that they exist and are important, may compound the "smallness-of-effect" problem cited earlier.

Brester and Schroeder's analysis of meat advertising includes brand advertising, but excludes health information, and their demand system excludes fish. Despite these differences, results are consistent between the two studies on the key issue of generic advertising effectiveness. In particular, Brester and Schroeder (p. 977) found that generic beef and pork advertising had no effect on beef or pork demand and negatively affected poultry demand. If a lower level of significance is accepted for the cross effects of beef and pork advertising on poultry consumption, these results conform with our findings for the updated sample in table 4. The significance of brand advertising in Brester and Schroeder's analysis, although difficult to interpret due to the omission of health information, suggests that brand advertising may indeed expand meat demand, an issue worthy of additional research.

\section{Concluding Comments}

A basic theme of this paper is that empirical estimates of economic parameters may be fragile and therefore it is important to examine robustness. Examining U.S. meats, we found that price, expenditure, and cholesterol-information 
elasticities were relatively robust to sample updating, but that estimated elasticities for generic advertising were unstable. Thus, while we can be confident that meat consumption patterns are influenced by relative prices, total meat expenditures, and health information, no such confidence can be placed in the effects of advertising.

The dominant pattern in U.S. meat consumption over the past two decades has been a steady increase in per capita poultry consumption, largely at the expense of beef consumption. Although changes in relative prices have influenced this pattern, our results suggest that structural change is at work. The basis for this claim, which contradicts other findings (e.g., Eales and Unnevehr), is that health information, trend (the Rotterdam model's intercept), or both are significant in each of the estimated equations. Moreover, the elasticity for cholesterol information in the poultry equation (1.54) far exceeds poultry's own-price elasticity $(-0.158)$ and poultry's cross-price elasticity with respect to beef price $(0.305)$. Thus, relatively small percentage changes in health information induce much larger changes in poultry consumption than equivalently small percentage changes in poultry price or beef price. An examination of the corresponding elasticities for beef yields similar conclusions with respect to beef consumption, although health information effects are less pronounced.

The finding that advertising affects are sensitive to sample period suggests more attention needs to be devoted to robustness in empirical studies of advertising effectiveness. In addition to sample updating, advertising parameters may be influenced by functional form (Piggott and Griffith; Alston, Chalfant, and Piggott; Green, Carman, and McManus), measurement error (Kinnucan and Belleza), and structural change (Kinnucan, Chang and Venkateswaran; Kinnucan and Venkateswaran; Ward and Dixon). Clearly, more research is needed to sort out the sources of advertising parameter instability and to identify possible remedies. In the meantime, about all that can be said about the generic advertising programs for beef, pork, and fish in the United States is that their effects are uncertain. Producers, the legal community, and policy makers, therefore, should be cautious about claims that are made for the efficacy of generic advertising campaigns for meat products.

[Received June 1995;

final revision received November 1996.]

\section{References}

Alston, J.M., and J.A. Chalfant. "The Silence of the Lambdas: A Test of the Almost Ideal and Rotterdam Models." Amer. J. Agr. Econ. 75(May 1993):304-13.

Alston, J.M., J.A. Chalfant, and N.E. Piggott. "Demand Response and Returns to Incremental Advertising in the Australian Meat Industry." Economic Analysis of Meat Promotion. H.W. Kinnucan, J., E. Lenz, and C.R. Clary, eds. Ithaca, NY: National Institute for Commodity Promotion Research and Evaluation, Cornell University, 1995.

Barnett, W.A. "Theoretical Foundations for the Rotterdam Model." Rev. Econ. Stud. 46(January 1979):109-30.

Barten, A.P. "Consumer Demand Functions Under Conditions of Almost Additive Preferences." Econometrica 32(January-April 1964):1-38. . "Maximum Likelihood Estimation of a Complete System of Demand Equations." Eur. Econ. Rev. 1(Fall 1969):7-73.

Basmann, R.L. "A Theory of Demand with Variable Consumer Preferences." Econometrica 24(January 1956):47-58.

Brester, G.W., and T.C. Schroeder. "The Impacts of Brand and Generic Advertising on Meat Demand." Amer. J. Agr. Econ. 77(November 1995):969-79.

Bronsard, C., and L. Salvas-Bronsard. "On Price Exogeneity in Complete Demand Systems." $J$. Econometrics 24(March 1984):235-47.

Brown, M.G., and J.-Y. Lee. "Alternative Specifications of Advertising in the Rotterdam Model." Eur. Rev. Agr. Econ. 20(1993):419-36.

"Theoretical Overview of Demand Systems Incorporating Advertising Effects." Commodity Advertising and Promotion. H.W. Kinnucan, S.R. Thompson, and H.S. Chang, eds. Ames IA: Iowa State University Press, 1992.

Brown, D., and L. Schrader. "Cholesterol Information and Shell Egg Consumption." Amer. J. Agr. Econ. 72(August 1990):548-55.

Capps, O., Jr., and J.D. Schmitz. "A Recognition of Health and Nutrition Factors in Food Demand Analysis." W. J. Agr. Econ. 16(July 1991):2135.

Chang, H.S., and H.W. Kinnucan. "Advertising, Information, and Product Quality: The Case of Butter." Amer. J. Agr. Econ. 73(November 1991):1195-203.

Clarke, D.G. "Econometric Measurement of the Duration of Advertising Effect on Sales." J. Market. Res. 13(November 1976):345-57.

Duffy, M. “Advertising and Alcoholic Drink Demand in the UK: Some Further Rotterdam 
Model Estimates." Int. J. Advertising 9(June 1990):247-57.

Duffy, M.H. "Advertising and the Inter-Product Distribution of Demand: A Rotterdam Model Approach." Eur. Econ. Rev. 31(July 1987):1051-70.

Eales, J.S., and L.J. Unnevehr. "Simultaneity and Structural Change in U.S. Meat Demand." Amer. J. Agr. Econ. 75(May 1993):259-68.

Goldberger, A.S. Functional Form and Utility: A Review of Consumer Demand Theory. Boulder CO: Westview Press, Inc., 1987.

Greene, W.H. Econometric Analysis, 2nd ed. New York: Macmillan Publishing Company, 1993.

Greene, W.H. LIMDEP Version 6.0 User's Manual and Reference Guide. New York: Econometric Software, Inc., 1992.

Green, R.D., H.F.,Carman , and K. McManus. "Some Empirical Methods of Estimating Advertising Effects in Demand Systems: An Application to Dried Fruits." W. J. Agr. Econ. 16(July 1991):63-71.

Hsia, C.J. "Advertising and Cholesterol Information Effects on U.S. Meat Demand," PhD dissertation, Auburn University, 1994.

Kinnucan, H., and E. Belleza. "Advertising Evaluation and Measurement Error: The Case of Fluid Milk in Ontario." Can. J. Agr. Econ. 39(July 1991):283-97.

Kinnucan, H.W., and M. Venkateswaran. "Generic Advertising and the Structural Heterogeneity Hypothesis." Can. J. Agr. Econ. 42(November 1994):381-96.

Kinnucan, H.W., H.S. Chang, and M. Venkateswaran. "Generic Advertising Wearout." Rev. Marketing and Agr. Econ. 61(December 1993):401-16.

Leading National Advertisers. AD \$ Summary. New York: Leading National Advertisers, Inc., all issues, 1975-1993.

McGuirk, A., P. Discoll, J. Alwang, and H. Huang. "System Misspecification Testing and Structural Change in the Demand for Meats." J. Agr. and Res. Econ. 20(July 1995):1-21.

Mizerski, R. "An Attribution Explanation of the Disproportionate Influence of Negative Information." J. Consum. Res. 9(December 1982):301-10.

Mountain, D.C. "The Rotterdam Model: An Approximation in Variable Space." Econometrica 56(March 1988):477-84.

Perez, A.M., M.R. Weimar, and S. Cromer. U.S. Egg and Poultry Statistical Series, 1960-90. Washington DC: U.S. Department of Agriculture, CED, ERS, Statist. Bull. No. 833, December 1991.

Piggott, N.E., and G.R. Griffith. Measuring the De- mand Response to Generic Advertising: The Case of the Australian Meat Industry. Research Working Paper Series No. 3/92, Economic Services Unit, New South Wales Agriculture, 1992.

Putman, J.J. and J.E. Allshouse. Food Consumption, Price, and Expenditure, 1970-1990. Washington DC: U.S. Department of Agriculture, ERS Statist. Bull. No. 840.

Robinson, L. J. and D. Colyer. "Reflections on Relevance of Professional Journals." J. Agr. and Appl. Econ. 26(July 1994):19-34.

Sakong, Y., and D. J. Hayes. "Testing the Stability of Preferences: A Nonparametric Approach." Amer. J. Agr. Econ. 75(May 1993):269-77.

Schmitz, J.D., and O. Capps, Jr. A Complete Systems Analysis of Nutritional Awareness and Food Demand. Texas A\&M Agr. Exp. Sta. Bull. 1712, March 1993.

Selvanathan, E.A. "Advertising and Consumer Demand: A Differential Approach." Econ. Letters 31(November 1989):215-19.

Stigler, G.J., and G. Becker. "“De Gustibus Non Est Disputatum'." Amer. Econ. Rev. 67(March 1977):76-90.

Telser, L.G. "Advertising and Cigarettes." J. Polit. Econ. 70(February-December 1962):471-99.

Theil, H. "The Information Approach to Demand Analysis." Econometrica 33(January 1965):6787.

. System-wide Explorations in International Economics, Input-Output Analysis, and Marketing Research. Amsterdam: North-Holland, 1980.

Thompson, S.R., and D.A. Eiler. "Determinants of Milk Advertising Effectiveness." Amer. J. Agr. Econ. 59(May 1977):330-35.

Tomek, W.G. "Confirmation and Replication in Empirical Econometrics: A Step Toward Improved Scholarship." Amer. J. Agr. Econ. 75(October 1993):6-14.

U.S. Department of Agriculture, Economic Research Service (USDA, ERS). Livestock and Poultry Situation and Outlook Report. LPS-43, August 1990.

Verma, V.K. "A Price Theoretic Approach to the Specification and Estimation of the Sales-Advertising Function," J. Bus. 53(July 1980):S115-S138.

Ward, R.W., and B.L. Dixon. "Effectiveness of Fluid Milk Advertising Since the Dairy and Tobacco Adjustment Act of 1983." Amer. J. Agr. Econ. 71(August 1989):730-40.

Ward, R.W., and C. Lambert. "Generic Promotion of Beef: Measuring the Impact of the U.S. Beef Checkoff." J. Agr. Econ. 44(September 1993):456-65. 